\title{
Effects of Garlic Extract, Allamanda Leaf Extract and Provax -200 on Seed Borne Fungi of Rice
}

\author{
F. Yeasmin, M. Ashrafuzzaman and I. Hossain ${ }^{*}$ \\ Department of Plant Pathology, \\ Bangladesh Agricultural University, Mymensingh - 2202, Bangladesh. \\ *Corresponding author and Email: dhossain69@gmail.com
}

Received: 22 February 2012

Accepted: 26 May 2012

\begin{abstract}
Seeds of rice were treated with Garlic (Allium sativum) clove extract @ 1:0, 1:1, 1:2 dilutions in water, allamanda (Allamanda cathartica) leaf extract@ @1:1, 1:2, 1:3 dilutions in water and Provax-200@ $0.3 \%$ for controlling seed borne fungi, where the seed samples of three rice varieties viz. Katharee, Gutee Aus and Kalijira were collected from farmer's storages of Bangladesh. The seed germination under control ranged from 64 to $77 \%$, where treatments resulted up to $100 \%$ germination. The identified seed borne fungi of rice were Bipolaris oryzae, Curvularia oryzae, Fusarium oxysporum, F. moniliforme, Nigrospora oryzae, Aspergillus flavus, Aspergillus niger and Penicillium sp., where prevalence of Bipolaris oryzae (7.5\%) and Fusarium moniliforme $(8.3 \%)$ were the maximum. All the treatments significantly reduced the seed borne fungi up to $100 \%$ over the control, where Provax was found best and was statically similar to garlic (1:1) extract against seed borne pathogen of rice
\end{abstract}

Keywords: Rice, seed treatments, garlic extract, allamanda leaf extract and Provax-200

\section{Introduction}

Rice (Oryza sativa L.) is the most important crop that dominates over other crops and covers $75 \%$ of the total cropped area where about $92 \%$ farmers grow rice in Bangladesh (Rekabder, 2004). Most of the major diseases of rice in the country are seed-borne (Fakir, 2002). The most destructive seed-borne fungi of rice are Bipolaris oryzae, Pyricularia oryzae, Sarocladium oryzae, Rhizoctonia solani, Bipolaris oryzae, Sclerotium rolfsii, Fusarium spp., Curvularia oryzae and Nigrospora oryzae. Natural plant extracts are important sources of new means and nonselective pesticide for control of plant diseases (Tripathi and Dubey, 2004). Many plant and plant products have been reported to be antimicrobials against plant pathogenic fungi
(Bowers and Locke, 2000). In the past couple of years, trials on the use of garlic bulb extract against several fungi were made and the results were highly promising (Islam, 2005). Garlic extract gave the best result in controlling seedborne fungal pathogens and seed germination of rice following neem leaf extract (Riazuddin et al., 2009). Allamanda (Allamanda cathertica) leaves are the source of many compounds with medicinal properties and found promising against fungi (Rumana, 2004). However, use of plant extract for seed treatment is very limited in Bangladesh. Several broad spectrum fungicides have been recommended for control of seedborne fungi of cereals. The chemical methods of disease management are expensive and nonjudicial use of seed treating chemical environmental pollution. Bangladeshi farmers 
mostly use their own saved seeds which are not certified. Although the seed system in Bangladesh is at a very rudimentary stage, a total of 5 lac tons of seeds including the seeds of cereals and other crops per year is required, out of which only $18 \%$ seeds are produced by different seed organizations with care but almost regardless of the health status (Hossain and Dey, 2011). The rest $82 \%$ of the seeds retained by the farmers remain uncertified with unknown quality and outside the supervision of Seed Certification Agency (Rashid and Fakir, 2000). It is unquestionable that proper seed treatment measures can substantially improve the quality of seed and significantly increase the yield. Farmers' saved seeds give lower germination rate, however, upon treatment significant increase in seed germination rate was obtained (Meah et al., 2004). It indicates that there is a scope of up gradation of farmers saved seeds through treatment. The present research was, therefore, undertaken to find out the effect of seed treatment with Garlic clove extract, Allamanda leaf extract and Provax-200 for controlling the seed borne fungal infections of rice for higher germination.

\section{Materials and Methods}

The experiment was conducted at the Seed Pathology Centre (SPC), Bangladesh Agricultural University (BAU), Mymensingh during the period of August, 2010 to October, 2011. Three rice varieties viz. Katharee, Gutee Aus, and Kalojira selected for the study were collected from farmer's storages of Bangladesh. Two plant species namely Garlic and Allamanda were collected and plant parts were chopped after cleaning in running tap water. The garlic extract was prepared by crushing garlic cloves in a blender with distilled water in 1:0, 1:1 and 1:2 ratios and the allamanda extract was prepared by crushing leaves and blended with distilled water in $1: 1,1: 2$ and $1: 3$ ratios. The extracts were filtered through cheese cloth. Selected seed samples of rice were treated with plant extracts by dipping method. The seeds were dipped in previously prepared garlic cloves extracts and Allamanda leaf extracts for half an hour. The extracts were drained out and the treated seeds were placed on filter paper for drying and were tested following the standard blotter method. For the chemical treatment, seeds were taken in a plastic container and treated with Provax-200 @ $0.3 \%$ of seed weight. Treated seeds were then tested following the standard blotter method (ISTA, 2001). The significance of differences between the treatments mean was evaluated following Completely Randomized Design (CRD) by using Duncan's Multiple Range Test (DMRT) following Gomez and Gomez (1984).

\section{Results and Discussion}

Germination of the seeds of rice varieties Katharee, Gutee Aus and Kalijira varied from $77-98 \%, 69-95 \%$ and $64-100 \%$, respectively depending on the variety and treatment condition, while the lowest germination was found under control (untreated seeds). Statistically the highest germination was found when seeds were treated with Provax - 200 though other treatments were found to show statistically similar effect on germination of seeds (Tables 1, 2 and 3). Seed treatment resulted in higher germination by $19.5-27.3 \%$, $33.3-37.7 \%$ and $46.9-56.3 \%$ in Katharee, Gutee Aus and Kalijira, respectively over the untreated control. Eight species of fungi recorded with the seeds of three varieties were Bipolaris oryzae, Curvularia oryzae, Fusarium oxysporum, F. moniliforme, Nigrospora oryzae, Aspergillus flavus, Aspergillus niger, and Penicillium sp.. Seed infection varied significantly with respect to varieties. The highest seed infection was recorded with Bipolaris oryzae by $7.5 \%$ and $F$. moniliforme by $8.3 \%$ in Kalijira variety. Nahar (2003) found Bipolaris oryzae, Fusarium oxysporum, Fusarium moniliforme, Trichoconis padwickii, Alternaria tenuis and Curvularia lunata in farmer's stored rice seeds. Among the varieties, the seeds of Kalijira were found to be more infected by seed-borne fungi than the other tested varieties. The fungi recorded from amongest the selected rice varieties were also found to vary. Total seed-borne infection (\%) was the highest in control $(16.0 \%, 7.5 \%$ and $26.8 \%$ in varieties Katharee, Gutee Aus and 
Kalijira, respectively). The predominant seed borne fungus Fusarium moniliforme ranged from $0.8 \%$ to $8.3 \%$, while the highest incidence of Fusarium moniliforme was $8.3 \%$ in Kalijira and the lowest $(1.0 \%)$ in Gutee Aus. The highest incidence of Bipolaris oryzae (7.5\%) was recorded in Kalijira and lowest in Gutee Aus (1.8\%). Incidence of Fusarium oxysporum was higher in Katharee (4.0\%) and lower in Kalijira (1.75\%). Incidence of Aspergillus flavus was the highest $(6.3 \%)$ in Kalijira and the lowest $(0.3 \%)$ in Gutee Aus. Incidence of Curvularia oryzae was higher $(2.0 \%)$ in Guteeaus and lower $(0.8 \%)$ in Katharee and Kalijira. Incidence of Nigrospora oryzae was higher in Kalijira (2.0\%) but not found in Katharee. Higher incidence of Penicillium sp. and Aspergillus niger were in Gutee Aus (1.0\%) and this fungus was not found in Kalijira.

Among the treatments, garlic extract (1:0) increased germination in Katharee by $23.4 \%$, Kalojira by $50.0 \%$ and Gutee Aus by $36.2 \%$ over control. The prevalence of total pathogens was reduced by $95.3 \%$ in Katharee, $100 \%$ in Guteeaus and $91.5 \%$ in Kalijira by using garlic clove extracts. This finding is in agreement with Riazuddin et al. (2009). Ahmed (2002) reported garlic extracts as more effective against
Bipolaris oryzae at $1: 1$ dilution. By using Allamanda leaf extracts germination percentage increased by $26.0 \%, 34.8 \%$ and $48.4 \%$, and total pathogen population reduced by $80 \%, 83.3 \%$ and $68.2 \%$, respectively in Katharee, Guteeaus and Kalijira. Islam (2005) found Allamanda (1:1) as the most effective in controlling seed-borne fungi of rice. In case of variety Katharee, Gutee Aus and Kalijira the highest germination $(100.0 \%)$ was found when the seeds were treated with Provax-200 and it increased germination rate by $27.3 \%, 37.7 \%$ and $56.3 \%$, respectively over control. By using Provax the total fungal population reduced by $96.9 \%, 100 \%$ and $99.1 \%$, respectively in Katharee, Guteeaus and Kalijira. This is also supports Kabir (2006) who observed the lowest prevalence of seed borne fungi in the farmer's seeds treated with Vitavax-200. In pursuit of environment friendly products or materials, especially botanical products, have been getting increasing importance. The results have unveiled some treatments which are ecofriendly and significantly effective. Therefore, there is plenty of scope to perform research on this issue in near future. Out of the treatments used, though Provax was found to be the best, garlic extract is highly desirable for treating seeds of rice in Bangladesh in consideration of the environmental issues.

Table 1. Effect of seed treatments on seed germination and seed-borne fungal infections of rice variety Katharee.

\begin{tabular}{|c|c|c|c|c|c|c|c|c|c|c|c|}
\hline \multirow[b]{2}{*}{ 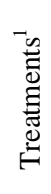 } & \multicolumn{2}{|c|}{ Seed Germination } & \multicolumn{9}{|c|}{$\%$ Prevalence of seed borne fungi } \\
\hline & $\begin{array}{c}\text { Germination } \\
(\%)\end{array}$ & $\begin{array}{l}\text { Germination } \\
\text { Increase over } \\
\text { control } \\
(\%)\end{array}$ & 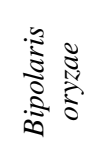 & 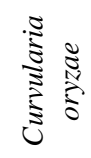 & 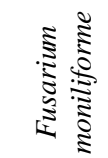 & 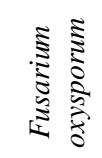 & 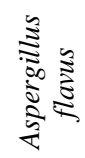 & 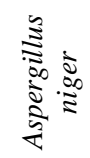 & 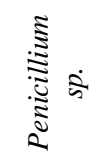 & 氶 & 总 \\
\hline $\mathrm{T}_{0}$ & $77.0 \mathrm{~b}$ & - & $7.0 \mathrm{a}$ & $0.8 \mathrm{a}$ & $2.3 \mathrm{a}$ & $4.0 \mathrm{a}$ & 0.8 & $0.8 \mathrm{a}$ & $0.5 \mathrm{a}$ & 16.0 & - \\
\hline $\mathrm{T}_{1}$ & $98.0 \mathrm{a}$ & 27.3 & $0.3 b$ & $0.0 \mathrm{~b}$ & $0.0 \mathrm{c}$ & $0.0 \mathrm{~b}$ & 0.0 & $0.0 \mathrm{~b}$ & $0.0 \mathrm{~b}$ & 0.5 & 96.9 \\
\hline $\mathrm{T}_{2}$ & $97.0 \mathrm{a}$ & 23.4 & $0.3 b$ & $0.0 \mathrm{~b}$ & $0.3 b c$ & $0.5 b$ & 0.0 & $0.0 \mathrm{~b}$ & $0.0 \mathrm{~b}$ & 1.0 & 93.8 \\
\hline $\mathrm{T}_{3}$ & $93.0 \mathrm{a}$ & 26.0 & $0.0 \mathrm{~b}$ & $0.8 \mathrm{a}$ & $0.3 \mathrm{bc}$ & $0.0 \mathrm{~b}$ & 0.0 & $0.0 \mathrm{~b}$ & $0.0 \mathrm{~b}$ & 0.8 & 95.3 \\
\hline $\mathrm{T}_{4}$ & $92.0 \mathrm{a}$ & 20.8 & $0.5 b$ & $0.0 \mathrm{~b}$ & $1.5 \mathrm{ab}$ & $0.8 b$ & 0.3 & $0.0 \mathrm{~b}$ & $0.0 \mathrm{~b}$ & 3.0 & 81.3 \\
\hline $\mathrm{T}_{5}$ & $97.0 \mathrm{a}$ & 19.5 & $1.0 \mathrm{~b}$ & $0.0 \mathrm{~b}$ & $0.8 \mathrm{abc}$ & $2.8 \mathrm{a}$ & 0.0 & $0.0 \mathrm{~b}$ & $0.0 \mathrm{~b}$ & 4.5 & 71.9 \\
\hline $\mathrm{T}_{6}$ & $95.0 \mathrm{a}$ & 26.0 & $0.5 b$ & $0.8 \mathrm{a}$ & $0.3 \mathrm{bc}$ & $1.3 \mathrm{bc}$ & 0.0 & $0.0 \mathrm{~b}$ & $0.0 \mathrm{~b}$ & 2.8 & 80.0 \\
\hline $\mathrm{T}_{7}$ & $91.0 \mathrm{a}$ & 23.4 & $1.0 \mathrm{~b}$ & $0.0 \mathrm{~b}$ & $2.0 \mathrm{a}$ & $2.8 \mathrm{a}$ & 0.0 & $0.0 \mathrm{~b}$ & $0.0 \mathrm{~b}$ & 5.8 & 64.1 \\
\hline$\overline{\mathrm{LS}}$ & $* *$ & & $* *$ & $*$ & $* *$ & $* *$ & NS & $* *$ & $* *$ & & \\
\hline
\end{tabular}


Table 2. Effect of seed treatments on seed germination and seed-borne fungal infections of rice variety Gutee Aus

\begin{tabular}{|c|c|c|c|c|c|c|c|c|c|c|}
\hline \multirow[b]{2}{*}{ 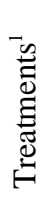 } & \multicolumn{2}{|c|}{ Seed Germination } & \multicolumn{8}{|c|}{$\%$ Prevalence of seed borne fungi } \\
\hline & $\begin{array}{c}\text { Germination } \\
(\%)\end{array}$ & $\begin{array}{l}\text { Germination } \\
\text { Increase } \\
\text { over } \\
\text { control }(\%)\end{array}$ & 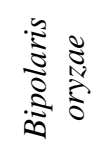 & 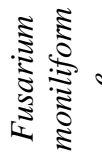 & 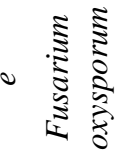 & 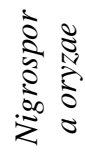 & 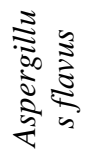 & 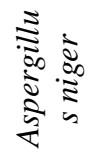 & 풍 & 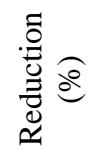 \\
\hline $\mathrm{T}_{0}$ & $69.0 \mathrm{~b}$ & - & $1.8 \mathrm{a}$ & 1.0 & $2.5 \mathrm{a}$ & $1.0 \mathrm{a}$ & 0.3 & $1.0 \mathrm{a}$ & 7.5 & - \\
\hline $\mathrm{T}_{1}$ & $95.0 \mathrm{a}$ & 37.7 & $0.0 \mathrm{c}$ & 0.0 & $0.0 \mathrm{~b}$ & $0.0 \mathrm{~b}$ & 0.0 & $0.0 \mathrm{~b}$ & 0.0 & 100.0 \\
\hline $\mathrm{T}_{2}$ & $94.0 \mathrm{a}$ & 36.2 & $0.0 \mathrm{c}$ & 0.0 & $0.3 b$ & $0.0 \mathrm{~b}$ & 0.0 & $0.0 \mathrm{~b}$ & 0.3 & 96.7 \\
\hline $\mathrm{T}_{3}$ & $93.0 \mathrm{a}$ & 34.8 & $0.0 \mathrm{c}$ & 0.0 & $0.0 \mathrm{~b}$ & $0.0 \mathrm{~b}$ & 0.0 & $0.0 \mathrm{~b}$ & 0.0 & 100.0 \\
\hline $\mathrm{T}_{4}$ & $93.0 \mathrm{a}$ & 34.8 & $0.2 \mathrm{c}$ & 0.3 & $0.3 b$ & $0.0 \mathrm{~b}$ & 0.0 & $0.0 \mathrm{~b}$ & 0.8 & 90.0 \\
\hline $\mathrm{T}_{5}$ & $93.0 \mathrm{a}$ & 34.8 & $0.8 \mathrm{abc}$ & 0.8 & $1.0 \mathrm{~b}$ & $0.0 \mathrm{~b}$ & 0.0 & $0.0 \mathrm{~b}$ & 2.5 & 66.7 \\
\hline $\mathrm{T}_{6}$ & $92.0 \mathrm{a}$ & 33.3 & $0.5 b c$ & 0.8 & $0.0 \mathrm{~b}$ & $0.0 \mathrm{~b}$ & 0.0 & $0.0 \mathrm{~b}$ & 1.3 & 83.3 \\
\hline $\mathrm{T}_{7}$ & $92.0 \mathrm{a}$ & 33.3 & $1.5 \mathrm{ab}$ & 0.5 & $0.5 b$ & $0.0 \mathrm{~b}$ & 0.0 & $0.5 \mathrm{ab}$ & 3.0 & 60.0 \\
\hline LS & $* *$ & & $* *$ & NS & $* *$ & $* *$ & NS & $* *$ & & \\
\hline
\end{tabular}

In a column, figure with common letter(s) do not differ significantly.

LS $=$ Level of significance, NS = Non significant, $* *$ indicates Significant at $1 \%$ level

Table 3. Effect of seed treatments on seed germination and seed-borne infection of rice variety Kalijira

\begin{tabular}{|c|c|c|c|c|c|c|c|c|c|c|}
\hline \multirow[b]{2}{*}{ 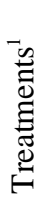 } & \multicolumn{2}{|c|}{ Seed Germination } & \multicolumn{8}{|c|}{$\%$ Prevalence of seed borne fungi } \\
\hline & $\begin{array}{c}\text { Germination } \\
(\%)\end{array}$ & $\begin{array}{c}\text { Germination } \\
\text { Increase } \\
\text { over } \\
\text { control }(\%)\end{array}$ & 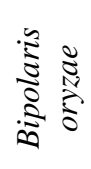 & 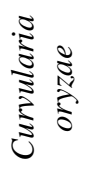 & 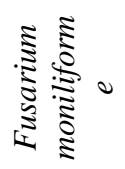 & 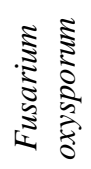 & 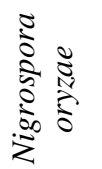 & 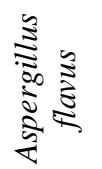 & 矛 & 氙 \\
\hline $\mathrm{T}_{0}$ & $64.0 \mathrm{~b}$ & - & $7.5 \mathrm{a}$ & $0.8 \mathrm{a}$ & $8.3 \mathrm{a}$ & $1.8 \mathrm{a}$ & $2.0 \mathrm{a}$ & $6.3 \mathrm{a}$ & 26.8 & - \\
\hline $\mathrm{T}_{1}$ & $100.0 \mathrm{a}$ & 56.3 & $0.0 \mathrm{~d}$ & $0.0 \mathrm{~b}$ & $0.0 \mathrm{~d}$ & $0.0 \mathrm{~b}$ & $0.0 \mathrm{c}$ & $0.0 \mathrm{~d}$ & 0.3 & 99.1 \\
\hline $\mathrm{T}_{2}$ & $96.0 \mathrm{a}$ & 50.0 & $0.5 \mathrm{~d}$ & $0.0 \mathrm{~b}$ & $0.3 \mathrm{~cd}$ & $0.0 \mathrm{~b}$ & $0.5 b c$ & $5.5 \mathrm{ab}$ & 6.5 & 75.7 \\
\hline $\mathrm{T}_{3}$ & $95.0 \mathrm{a}$ & 48.4 & $2.5 \mathrm{c}$ & $0.0 \mathrm{~b}$ & $1.5 \mathrm{c}$ & $1.5 \mathrm{a}$ & $1.3 \mathrm{ab}$ & $0.5 \mathrm{~d}$ & 7.3 & 72.9 \\
\hline $\mathrm{T}_{4}$ & $94.0 \mathrm{a}$ & 46.9 & $0.3 \mathrm{~d}$ & $0.0 \mathrm{~b}$ & $0.3 \mathrm{~cd}$ & $0.3 b$ & $0.8 \mathrm{bc}$ & $0.5 \mathrm{~d}$ & 2.0 & 92.5 \\
\hline $\mathrm{T}_{5}$ & $95.0 \mathrm{a}$ & 48.4 & $4.0 \mathrm{bc}$ & $0.0 \mathrm{~b}$ & $1.0 \mathrm{~cd}$ & $0.0 \mathrm{~b}$ & $0.0 \mathrm{c}$ & $3.5 \mathrm{c}$ & 8.5 & 68.2 \\
\hline $\mathrm{T}_{6}$ & $95.0 \mathrm{a}$ & 48.4 & $5.0 \mathrm{~b}$ & $0.0 \mathrm{~b}$ & $4.0 \mathrm{~b}$ & $0.0 \mathrm{~b}$ & $0.0 \mathrm{c}$ & $0.8 \mathrm{~d}$ & 9.8 & 63.6 \\
\hline $\mathrm{T}_{7}$ & $94.0 \mathrm{a}$ & 46.9 & $4.0 \mathrm{bc}$ & $0.0 \mathrm{~b}$ & $4.8 \mathrm{~b}$ & $0.0 \mathrm{~b}$ & $0.0 \mathrm{c}$ & $4.8 b$ & 13.5 & 49.5 \\
\hline LS & $* *$ & & $* *$ & $* *$ & $* *$ & $* *$ & $* *$ & $* *$ & & \\
\hline
\end{tabular}

In a column, figure with common letter(s) do not differ significantly. LS = Level of significance NS $=$ Non significant, $* *$ indicates significant at $1 \%$ level, $*$ indicates significant at $1 \%$ level

${ }^{1}$ Treatments

$\mathrm{T}_{0}=$ Control (without treatment)

$\mathrm{T}_{1}=$ Provax 200WP $(@ 0.3 \%)$

$\mathrm{T}_{2}=$ Garlic clove extract $(1: 0)$

$\mathrm{T}_{3}=$ Garlic clove extract $(1: 1)$

$\mathrm{T}_{4}=$ Garlic clove extract $(1: 2)$

$\mathrm{T}_{5}=$ Allamanda leaf extract $(1: 1)$

$\mathrm{T}_{6}=$ Allamanda leaf extract $(1: 2)$

$\mathrm{T}_{7}=$ Allamanda leaf extract $(1: 3)$ 


\section{Conclusions}

Effect of garlic extract was found statistically similar to chemical fungicide Provax - 200 for controlling the seed borne fungi of rice. Therefore, it may be concluded that garlic extract can successfully be used for controlling seed borne fungal pathogens of rice instead environment hazardous chemicals for treating seeds of rice in Bangladesh.

\section{References}

Ahmed, M. F. 2002. Efficacy of some fungicides and plant extracts against Bipolaris oryzae. M.S. Thesis, Dept. of Plant Pathology, Bangladesh Agricultural University (BAU), Mymensingh, Bangladesh.

Bowers, J. H. and Locke, J. C. 2000. Effect of botanical extracts on the population density of Fusarium oxysporum in soil and control of Fusarium wilt in the greenhouse. Plant Disease, 84: 300-305.

Fakir, G.A. 2002. An annotated list of seedborne diseases in Bangladesh. Seed Pathology Centre, Dept. of Plant Pathology, BAU, Mymensingh, Bangladesh.

Gomez, K. A. and Gomez, A. A. 1984. Statistical Procedure for Agricultural Research ( $2^{\text {nd }}$ edition). International Rice Research Institute, J. Willey International Scientific Publication. 28-192 pp.

Hossain, I. and Dey, P. 2011. Annual Report. Seed Pathology Centre, BAU, Mymensingh, Bangladesh, 5-6 pp.

Islam, M. D. 2005. Studies on the significance of seed-borne fungal pathogen of rice. M.S. Thesis. Dept. of Plant Pathology, BAU, Mymensingh, Bangladesh.

ISTA (International Seed Testing Association). 2001. International Rules for Seed Testing. Rules amendments. Seed Science and Technology, 29(2): 1-127.
Kabir, M. H. 2006. Effect of physical and chemical seed treatment on leaf spot (Bipolaris sorokiniana) and grain yield of wheat. MS Thesis, Department of plant Pathology, Sher-e-Bangla Agril. University, Dhaka, Bangladesh.

Meah, M. B., Islam, M. R. and Islam, M. M. 2004. Development of an Integrated Approach for the Management of Phomopsis blight and fruit rot of Eggplant in Bangladesh. Annual Research Report, Dept. of Plant. Pathology, BAU, Mymensingh, Bangladesh, $57 \mathrm{p}$.

Nahar, K. 2003. Seed quality and seedling health of farmer's rice of Bogra district. M.S. Thesis, Dept. of Plant Pathology, BAU, Myrnensingh, 77-78 pp.

Rashid, A. Q. M. B. and Fakir, G. A. 2000. Impact of seed health on sustainable crop production in Bangladesh. Co-operation, Yearly J. Published by Co-operative Dept. Samabaya Sadan, 9/D, Motijheel Commercial Area, Dhaka-1000, Bangladesh, 24-36 pp.

Rekabder, M. F. H. 2004. Dhan Chasher Nana Katha. Krishikatha, 64(2):39-40.

Riazuddin, M., Rahman, H., Haque, A. H. M., Islam, M. S. and Kamal, M. M. 2009. Efficacy of botanicals for controlling seed borne fungal pathogens and seed germination of rice. Eco-friendly Agricultural Journal, 2(9): 814-817.

Rumana, I. 2004. Chromatographic separation of components in garlic bulb and allamanda leaf extracts inhibitory to Phomopsis vexans. MS Thesis, Dept. of Plant Pathol. BAU, Mymensingh, 35 pp.

Tripathi, P. and Dubey, N. K. 2004. Exploitation of natural products as an alternative strategy to control postharvest fungal rotting of fruit and vegetables. Postharvest Biology and Technology, 32:235-245. 